\title{
Social entrepreneurship in Saint-Petersburg as green economy aspect
}

\author{
Olga Ignatjeva ${ }^{1, *}$ and Alexander Pletnev ${ }^{2}$ \\ ${ }^{1}$ Political governance department, St. Petersburg University, 199034, Universitetskaya emb., 7/9, St. \\ Petersburg, Russia \\ ${ }^{2}$ Philosophy and sociology department, St. Petersburg University of the Ministry of Internal Affairs of \\ the Russian Federation, 198206, Pilot Pilyutov str., 1, St. Petersburg, Russia
}

\begin{abstract}
Identification of the prospects for the social entrepreneurship expansion as one of the aspects of green economy uses the example of St. Petersburg. We use a statistical method for processing nominal data with the aid of SPSS. The study revealed that social-oriented not-for-profit organizations and government social agencies work with the same social groups and offer similar services. Therefore, to increase the competitiveness of not-for-profit organizations, these organizations should provide services at a high client-oriented level. We found that because of the lack of permanent sources of funding, the problem of fundraising exists. The results of the current study are applicable for improvement of commercial and social practices of social-oriented not-for-profit organizations, in the expansion of services for the additional professional education of such organizations' personnel, in the development of practices in fundraising and crowdsourcing, in improving applications for grant support from the state, in the diversification of services. We revealed that social-oriented not-for-profit organizations and state social agencies work with the same social groups and offer similar services; we found that the problem of fundraising becomes a priority for this organizations; personnel in these organizations has different education; the representatives of notfor-profit organizations understand the purposes of social entrepreneurship.
\end{abstract}

\section{Introduction}

Social entrepreneurship is a type of business activity in the social sphere, which is aimed, on the one hand, to create a public good, and on the other hand, to achieve sustainable selfsufficiency of its producer. Small and medium-sized business as well as social-oriented notfor-profit organizations can carry out this type of activity. At the same time, for the former, this is a way of declaring social responsibility, reaching a new level of communication with federal and regional authorities, for the latter, i.e. for social-oriented not-for-profit organizations, this is an opportunity to solve both the problem of fundraising and achieve the goal for which the organization exists.

\footnotetext{
*Corresponding author: olga7919@mail.ru
} 
In any country, governments at the national and regional levels, as well as municipalities, have an interest in involving civil society representatives in addressing the social issues they are responsible for. Encouraging social entrepreneurship allows you to create a competitive environment in the provision of social services, improves their quality, and also contributes to the formation of a social system that smooths out contradictions between different layers of the population.

An essential aspect of the development of social entrepreneurship is the legal regulation of this activity, which can help social entrepreneurs solve the social problems of the population. Social entrepreneurs actively develop this sphere, and politicians make laws at the state and regional levels. In particular, if in 2010 in the U.S. only the state of Maryland had a law on social entrepreneurship at the regional level, now it is in thirty-five such states. The governments in in all EU countries make laws regulating social entrepreneurship. You can see a similar trend of the rapid development of legal regulation of social entrepreneurs around the world.

The Russian politicians also make attempts to regulate this type of activity through legislation. So, on May 20, 2011, Order of the Ministry of Economic Development of the Russian Federation No. 227 "On the organization of competitive selection of constituent entities of the Russian Federation" was enacted. The government grant budgets for the financial support of small and medium enterprises activities. On May 15, 2015, the Committee on Entrepreneurship and Consumer Market Development of St. Petersburg, by decree No. 1711-r, approved the program "On approval of the special program "Support for social entrepreneurship". In 2019, the Federal Law on Social Entrepreneurship entered into force. Experts believe that the adoption of this regulatory document will contribute to the development of entrepreneurship in the social sphere.

The study of the phenomenon of social entrepreneurship allows us to identify current trends occurring in it, and solve pressing problems. Their solution will increase the number of entities engaged in this field and make a better system of social services for people, consisting not only of state social agencies but also of commercial and not-for-profit organizations. Scientific research in this area serves as the basis for the preparation of legal acts and programs that regulate social entrepreneurship and contribute to the development of this type of activity.

An important direction of scientific research is to compare the specifics of the experience of social entrepreneurship in a particular region with international practice. Such comparisons can be very beneficial for social entrepreneurs and government representatives to improve social entrepreneurship. The research of social entrepreneurship becomes especially relevant if they study social entrepreneurship in the frame of the digital society [1-5].

In this research, we were primarily interested in the process of social entrepreneurship development in St. Petersburg. On October 11, 2019 the forum of not-for-profit organizations "Social Petersburg: Together with the City" took place. We as the representatives of St. Petersburg State University conducted an empirical study in the field of social entrepreneurship there. Its basic goal was to identify prospects for the expansion of social entrepreneurship in the activities of Saint Petersburg not-for-profit organizations using the example of St. Petersburg.

\section{Literature Review}

The concept of social entrepreneurship in scientific literature is versatile and reflects a wide range of tasks and features. In English literature, the researchers first mentioned a term "social entrepreneurship" in the 1960s [6]. However, in practice, this phenomenon has a quite a long story both abroad and in Russia. We can mention the names of Florence 
Nightingale, a founder of the first nursing school in the UK, John of Kronstadt, who created the House of Hard Work where everyone in need could find work and a shelter, and Nobel Prize winner Muhammad Yunus, who proposed the concept of microcredit on preferential terms for socially vulnerable people.

Further, we will discuss the different notions of a social entrepreneur in a modern scientific literature. When understanding social entrepreneurship, a group of researchers focuses on innovation. The social entrepreneur is the one who creates and implements innovation [7]. Social entrepreneurs are people with innovative spirit and skills [8]. Social entrepreneurs are individuals with an innovative approach to solving the most pressing social problems. They are both dreamers and "avid" realists, who think primarily about the practical application of their ideas [9]. With their intuition and knowledge, they can easily navigate the market and respond to changes in it [10].

Some researchers on social entrepreneurship prioritize people [11] who understand how to solve a social problem that the state cannot solve effectively. Social entrepreneurs find and combine resources (volunteers, platforms and finances) and use their potential to solve a problem [12]. Social entrepreneurs are like "a messenger of the change" in the social sphere [13]. A social entrepreneur can risk in the name of people in need [14]. They can lead, organize a team and solve social problems in the most effective way [15].

Some scholars focus on the rejection of social entrepreneurship from a profit orientation. We can say that the basis of this kind of activity is the creation of non-for-profit organizations [16], which exist to settle social problems and implement entrepreneurial activities for self-sufficiency and financial stability [17].

Ideologically oriented researchers consider social entrepreneurship primarily as a way to solve the problems of needy groups of the population. In this regard, they often understand social entrepreneurship as actions or processes undertaken to improve public welfare via the new enterprise creation or improvement of managerial processes of existing business units [18].

The essence of social entrepreneurship is to solve or mitigate social problems. Its main characteristics are sustainable and measurable achievements, creativity, self-sufficiency, ability to solve social problems through earnings from own market activities [19]. The main trait of social entrepreneurship is scalability and replicability - increasing the scale of activity of a social enterprise (nationally and internationally) and disseminating experience (models) to increase social impact [20]. Also, it is necessary to stress that an entrepreneurial approach is the ability of a social-oriented not-for-profit organizations to see market failures, looking for a new solution, combine resources, create a highly effective decision with influence for a long perspective [21].

Social entrepreneurship differs from ordinary entrepreneurship in its purpose. It serves a socially vulnerable category of the population, who cannot independently achieve positive changes in their lives. At the same time, social entrepreneurship is the generation of ideas with their subsequent implementation in the form of finished products or services to mitigate social problems in society [22].

Most specialists believe that entrepreneurship has a strong influence on the development of a society regardless of the direction of activity. It may be the development of new technologies and the formation of a high-income enterprise or innovative economic activity [23].

Generally, we can characterize the term "social entrepreneurship" in a context of growing demand [24] both by the relative novelty of the phenomenon and by the different social ideas that differ in content, target groups and states [25].

Reflecting a global trend, the phenomenon of social entrepreneurship exists not only in practice but also becomes an object of study of social and economic sciences. Since 1995, western researchers have created many different definitions of the term "social 
entrepreneurship." Among the researchers of this phenomenon, it is advisable to mention the names of D. Bortstein, G. Dees, S. Zahra, C. Leadbeater, D. Austin, G. Stevenson, D. Thompson and others. Russian researchers of this phenomenon are A. A. Moskovskaya, M. L. Batalina, L. D. Taradina (Moscow, Higher School of Economics, Institute of Social Process Management); E. Yu. Blagov, Yu. N. Arai (St. Petersburg, GSOM, St. Petersburg State University); A.N. Makarevich, T. Yu. Sazonova (Great Novgorod, Novgorod University after Yaroslav Mudriy).

According to the Our Future fund, which exists simnce 2007 to support social projects, social entrepreneurship is now especially in demand in the areas of preschool education, accompanying the elderly and disabled, the release of socially significant products, improving the quality and accessibility of medical services, employing young people, and addressing environmental issues, etc.

Modern society is increasingly in need of social-oriented business [26], where entrepreneurs, not only those who work in the development of social business, but also entrepreneurs willing to work not only for their interests only, but also for the prosperity of the society [27].

Many experts believe that social entrepreneurship is not a field of entrepreneurship in general [28] since making a profit is not its main goal. Social entrepreneurs continue to explore a variety of new areas of activity, from combating global climate change [3] to responding to the impact of the coronavirus pandemic [29].

The development of social entrepreneurship remains a relevant topic for practical activity and scientific research; social entrepreneurs open up new areas of activity; at the same time, social responsibility begins to play an increasing role in traditional entrepreneurship. The altruistic motives are engines for the most science-intensive and advanced forms of doing business. Social entrepreneurship is unique in that it allows us to solve social problems without spending resources in state and local budgets. Social entrepreneurs are active economic activities [30] and at the same time create a selfsustaining way of creating social good [31]. [32].

Social entrepreneurship is intermediate between traditional business and philanthropy

The main difference between social entrepreneurship and business is that social entrepreneurs do not aim to make a profit [33]. Unlike traditional charity, social entrepreneurs can create long-term [34] ways of solving social problems. A distinctive feature of social entrepreneurship as a way to solve the problems of vulnerable groups is the ability to scale up efforts, which allows us to spread to other regions we are successful and technologies of social entrepreneurship.

In all countries, social entrepreneurs create successful business models [35] that have a huge positive impact on society as a whole.

\section{Methodology}

The current study presents the empirical research with the focus on the detection of prospects for the expansion of social entrepreneurship in the activities of Saint Petersburg not-for-profit organizations. To achieve a goal, the authors have to solve the following tasks:

1. To study theoretical approaches to the phenomenon of social entrepreneurship.

2. To systematize the activities in the framework of this phenomenon.

3. To analyze the features of a social not-for-profit organization as subjects of social entrepreneurship.

4. To reveal the attitude of social-oriented not-for-profit organizations to the future of social entrepreneurship and possible directions for its development. 
The scientific paradigm for the interpretation of social research findings is social constructivism (P. Berger, T. Luckman). The research methods used in this study are survey, qualitative analysis of documents and ground theory.

On October 11, 2019, the forum of non-profit organizations Social Petersburg "Together with the City" took place in St. Petersburg with the aid of the Committee on Youth Policy and Interaction with Public Organizations, in which we conducted an empirical study on the theme: "Development social entrepreneurship in the activities of social-oriented not-forprofit organizations in St. Petersburg". To solve the set tasks, we used the survey method with the author's questionnaire (Appendix 1), as well as the document analysis method. The sample, formed at random, amounted to 72 social-oriented not-for-profit organizations, consisted of their specialists and managing directors. We use frequency analysis to reveal trends and contingency tables that allows to find a correlation between nominal variables.

Researchers use statistical analysis to process survey results. After receiving the raw data, it is necessary to encode the answer options for each question. If the questions were open-ended, and there were many answer choices, it is necessary to enlarge and categorize such data. For example, we can include mathematical and engineering education in the enlarged category "technical education". The questionnaire mainly involves the use of nominal data (verbal symbols). It is difficult to rank them in terms of little or much, bad or good. The researcher also usually has a small sample available, which makes it difficult to use statistical methods designed for data with normal distribution.

In the case of quantitative data, there are many descriptive mathematical models and coefficients. They are frequency analysis, correlation analysis and regression analysis. Sometimes it is useful to apply multivariate models. The nominal data that researchers use in sociological studies, dramatically diminish the variety of applied statistical methods. In this case, for the analysis of data are applicable tables of conjugation, chi-square, conjugation coefficient, Cramer's coefficients, frequency and correspondence analysis.

In our research, we use frequency analysis, contingency tables with Chi-square, Cramer's coefficients. As soon as we use multiple answer questions, we code answers as null or one and then calculate frequency with the use of the software statistic package SPSS.

\section{Main Findings}

Social entrepreneurship is a main sphere of social activity which allow to solve the important social problems, decrease the burden of the state regarding solving pressing social problems. As a result, a state supports it, organizing competition for grants among subjects of social entrepreneurship. The entrepreneurs can realize this type of activity in different directions. For example, the English site bestsmallventure.com ("The Best Small Enterprise") in 2017 indicated 15 best ideas for creating a social business. Here we can mention a social supermarket where poor people can buy products at the maximum discount; fair microfinance; social culinary, as well as the digital market as creating a platform through which customers could contact manufacturers to avoid a chain of intermediaries.

As a result of our research, we can mention the following results.

First of all, we found that state social agencies and social-oriented not-for-profit organizations work with the same social groups and present similar services. It means that to increase the competitiveness of not-profit organizations, social-oriented not-for-profit organizations should offer services at a very high level.

Second, we revealed that the problem of fundraising becomes a priority for socialoriented not-for-profit organizations because of the lack of permanent sources of financing. 
Social entrepreneurship as well as grants and donations also are the major ways of financial survival for social-oriented not-for-profit organizations.

Third, the study of education and competences of the staff in social-oriented not-forprofit organizations showed that the most part of their employees has higher education in different spheres (from specialists in social professions to engineers). It is a result of the current situation connected with a political and economic difficulties that take place in Russia during the last thirty years. It is very important findings that representatives of social-oriented not-for-profit organizations believe that they don't need to have proper education in a social sphere and present the specific documents to an employer. However, the specific competences in a social sphere will increase the viability of the social-oriented not-for-profit organizations. Especially it concerns the implementation of fundraising functions. Nowadays it becomes clear for managers of such organizations and ordinary employees should understand it as well.

Fourth, the research found that representatives of social-oriented not-for-profit organizations in St. Petersburg understand very well the specifics of social entrepreneurship as a professional activity. They believe that this activity has a future and consider that this type of activity has the most importance in the field of improvement the quality of life for elderly people, social support of disabled people, mass sports, prevention of child abandonment, scientific, technical and artistic creativity, the opening of care homes, in the sphere of interethnic cooperation and migration policy as well as in the development of the additional education activity.

Consequently, the social entrepreneurship is an important activity both for society and for the non-for-profit organization itself. It allows to solve the most important social problems, decreasing social tension. It creates new working places, allows to realize their potential for such companies' employees and finds a support for ordinary people in need.

\section{Analysis}

On October 11, 2019 within the framework of the forum of non-for-profit organizations "Social Petersburg: Together with the City" we conducted a survey among representatives of social-oriented non-for-profit organizations of St Petersburg. The total sample consisted from seventy-two respondents from different social-oriented non-for-profit organizations. We use our own questionnaire and add it in the Appendix of this article. The data was processed with SPSS.

One of the main questions in the survey was to clarify the target groups for socialoriented not-for-profit organizations. In accordance with the survey findings, social oriented not-for-profit organizations in St. Petersburg mainly work with people with disabilities (48.6\%), with children and adolescents living in families $(37.5 \%)$, and lowincome families ( $31.9 \%$ ), with children and adolescents without parental care $(27.8 \%)$, as well as elderly $(27.8 \%)$ and large families $(25 \%)$. Also, the target groups for social-oriented not-for-profit in our city are migrants $(11.10 \%)$, homeless $(9.7 \%)$, unemployed $(9.7 \%)$, widows $(6.9 \%)$, and alcoholics $(5,6 \%)$ and addicted to psychoactive substances $(5.6 \%)$ (Figure: 1). As we can see such organizations exists to assist poor people in the most cases [36].

Accordingly, we can conclude that not-for-profit organizations mainly work with same target group as the main participants in the social services market, which are state social agencies. We mean elderly and disabled people, low-income families and orphans [37]. This trend confirms the fact that there is a competition between state and not-state organizations in the social sphere [38], the outcome of which is not in favour of the latter. 


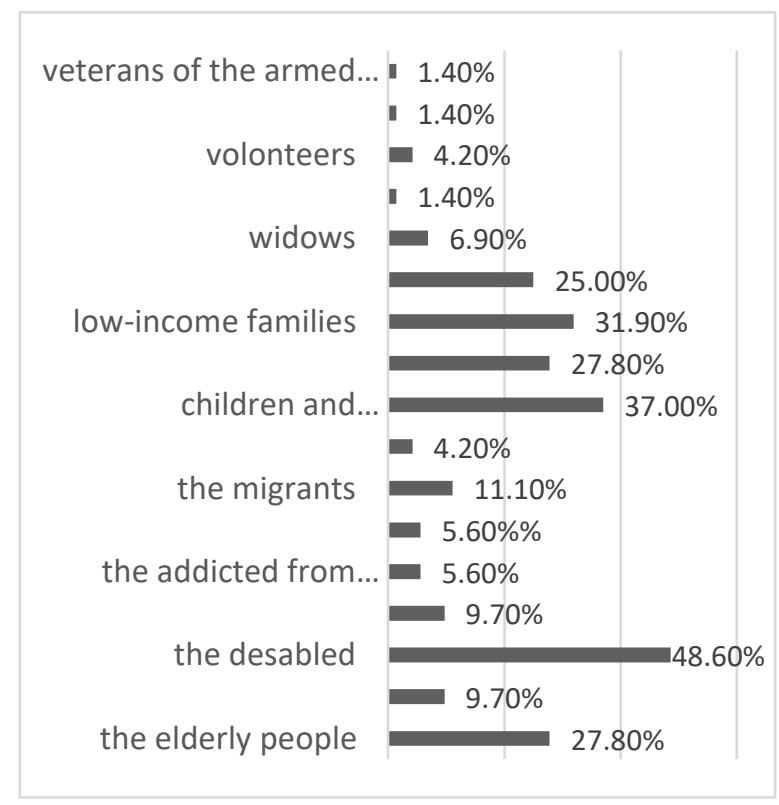

Fig. 1. Client groups of not-for-profit organization in St Petersburg.

How to survive social-oriented not-for-profit organizations and become an equal player in the social services market? What competitive advantage can they have? The fact is that the involvement of civil society structures in the provision of social services, such as social not-for-profit organizations, allows taking into account the interests of consumers. It implements the targeted nature of the provision of services, involving non-state resources in this process (grants from public funds, funds of commercial organizations and donations) [39]. In addition, social-oriented not-for-profit organizations adapt more quickly to new social conditions [40], generate new ideas, adapt to changed rules. All this allows them to offer different social services with high quality [41], and to provide them with, which is quite important, for free.

During the study, we asked representatives of social-oriented not-for-profit organizations the question "Does your organization offer free social services?" We received the following answers. It turned out that $59.20 \%$ of social-oriented not-profit organizations offer their customers free services. At the same time, $12.7 \%$ of not-for-profit organizations provide paid services, and $19.7 \%$ of not-for-profit organizations offer both paid and free services. This statistics indicates the efficiency of the functioning of social-oriented not-for-profit organizations in St. Petersburg, their ability to withstand competition from government agencies, since even in the absence of constant funding, about $60 \%$ of social-oriented notfor-profit organizations can offer free services to the population [42].

The logical question is "What kind of free services do social-oriented not-for-profit organizations offer?" Perhaps these services are unique and do not overlap with the services offered by state institutions of a social profile?

Among the respondents who provide free services, we revealed that social-oriented notfor-profit organizations most often provide free training services for people (13.90\%), legal advice $(9.70 \%)$ and social support $(6.90 \%)$. They also provide psychological counselling $(4.20 \%)$, social services $(4.20 \%)$ and emergency services $(4.20 \%)$ (Figure: 2$)$. Thus, following Article 21 of the Federal Law No. 442 dated 12.28.2013 "On the Basics of Social Services for Citizens in the Russian Federation", we can see that social-oriented not-forprofit organizations provide the same social services as the corresponding state agencies. 
Therefore, we can conclude that the quality of the services provided is high enough, because the consumer chooses in favour of a not-for-profit organization [43].

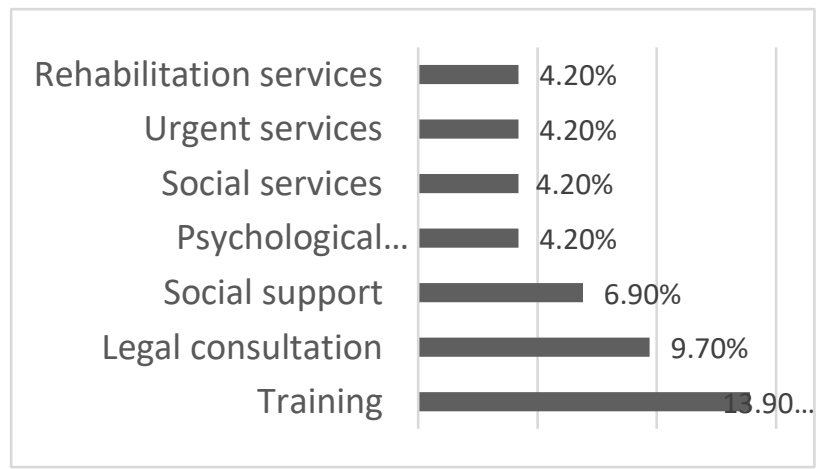

Fig. 2. The types of free services offered by not-for-profit organization.

A large number of specialists in social-oriented not-for-profit organizations have diplomas of helping professions, which include specialists in social work, psychologists, teachers $-26.4 \%$ of respondents. Next come specialists in technical specialties (engineers, programmers, mathematicians) - 16.7\%. 13.9\% are administrative specialties (managers). $11.10 \%$ are economists, $9.7 \%$ - lawyers, $8.3 \%$ - public relations and media specialists. Finally, 5.6\% are analysts, which include graduates of sociological and political science specialties. Therefore, specialists of helping professions are not the overwhelming majority among the staff of the social-oriented not-for-profit organizations [44]. The summation of other professions gives a greater share of other professions (technical, economic, legal, administrative) in this sample. Also, during a survey, we revealed that most employees in such organizations consider that it is not necessary to have a special education to work in this sphere [45].

The next regular question in the questionnaire is the question of the sources of financing the activities of social-oriented not-for-profit organizations that allow them not only to function but also to provide social services for free. The results indicate that the primary source of financing the activities of social-oriented not-for-profit organizations in St. Petersburg are grants and donations (77.8\%). In the next place there are financing from the activities of the most social-oriented not-for-profit organization (self-sufficiency) $-23.6 \%$. In third place is the funding of social-oriented not-for-profit organization activities from sources of the state budget (13.9\%). Other sources included sources of state order and free, volunteer work. We can support our findings with the another research [46].

Hypothesis 1: There is a relationship between question 4 (types of financial sources of social-oriented non-for-profit organizations) and question 3 (availability of free services). When analyzing nominal data using contingency tables and Chi-square, Phi and V Cramer's coefficients, we couldn't find the relationship between the type of funding source and the availability of free services, therefore, we couldn't confirm this hypothesis. Consequently, the presence of a constant source of funding for social-oriented not-for-profit organizations is not a necessary condition for the provision of free social services to the population.

Hypothesis 2: The study hypothesized that there is a relationship between question 2 (client groups of social non-for-profit organizations) and question 3 (types of free social services offered by social non-for-profit organizations).

When analyzing nominal data using contingency tables and $\mathrm{X}$-square, Phi and $\mathrm{V}$ Cramer's coefficients, we could find a relationship between the following items. 
First, there is a connection between the client group of disabled people and the provision of social support services (the connection between variables is valid with the significance level $0.028(\alpha<0.05))$. Please see Table 1 .

Table 1. Measures for Revealing a Connection Between a Target Group of Disabled People and a Kind of Social Services.

\begin{tabular}{|c|c|c|c|}
\hline \multicolumn{2}{|l|}{} & Value & $\begin{array}{c}\text { Approximate } \\
\text { Significance }\end{array}$ \\
\hline Pearson Chi-Square & & $4.808^{\mathrm{a}}$ & .028 \\
\hline Nominal by Nominal & Phi & -.258 & .028 \\
\hline N of Valid Cases & Cramer's V & .258 & .028 \\
\hline & 72 & & \\
\hline
\end{tabular}

Second, there is a connection between a client group of people with alcohol addiction and the provision of psychological counseling services (the connection between variables is valid with the significance level $0.032(\alpha<0.05))$. Please see Table 2.

Table 2. Measures for Revealing a Connection Between a Target Group of People With Alcohol Addiction and a Kind of Social.

\begin{tabular}{|c|c|c|c|}
\hline Services & Value & $\begin{array}{c}\text { Approximate } \\
\text { Significance }\end{array}$ & \\
\hline Pearson Chi-Square & & $4.604^{\mathrm{a}}$ & .032 \\
\hline Nominal by Nominal & Phi & .253 & .032 \\
\hline & Cramer's V & .253 & .032 \\
\hline N of Valid Cases & 72 & & \\
\hline
\end{tabular}

Third, there is a connection between a client group of low-income families and the provision of urgent services (the connection between variables is valid with the significance level $0.02(\alpha<0.05)$. Please see Table 3.

Table 3. Measures for Revealing a Connection Between a Target Group of Low-Income Families and a Kind of Social Services.

\begin{tabular}{|l|c|c|c|}
\hline & Value & $\begin{array}{c}\text { Approximate } \\
\text { Significance }\end{array}$ & \\
\hline Pearson Chi-Square & & $9.391^{\mathrm{a}}$ & .002 \\
\hline Nominal by Nominal & Phi & .361 & .002 \\
\hline N of Valid Cases & Cramer's V & .361 & .002 \\
\hline
\end{tabular}

Fourth, there is a connection between a client group of large families and a provision of social services (the connection between variables is valid with the significance level 0.015 $(\alpha<0.05))$. Please see Table 4.

Table 4. Measures Revealing a Connection Between a Target Group of Large Families and a Kind of Social Services.

\begin{tabular}{|c|c|c|c|}
\hline & Value & Approximate Significance & \\
\hline Pearson Chi-Square & & $5.901^{\mathrm{a}}$ & .015 \\
\hline Nominal by Nominal & Phi & .286 & .015 \\
\hline & Cramer's V & .286 & .015 \\
\hline N of Valid Cases & 72 & & \\
\hline
\end{tabular}

Thus, we can conclude that social-oriented not-for-profit organizations must provide social services at a high, customer-oriented level to remain competitive in the social services market and favourably differ from state social agencies, especially since both players are oriented towards the same client groups and offer the same set of services [47]. 
The study shows that there are difficulties in functioning of social-oriented not-for-profit organizations. They need to find livelihoods, which is uncharacteristic for government agencies with budget funding. Sources of funds are mainly grants and donations. Also, social entrepreneurship can help maintain the viability of a social-oriented not-profit organization [48], the use of which helps to solve the issue of self-sufficiency $[49,50]$ and the effective achievement of its goals.

\section{Conclusion}

In St. Petersburg social entrepreneurs work in a highly competitive environment with the state social assistance agencies. This competition is because of social entrepreneurs help the same group of needy as government agencies and provide similar services. To successfully compete with the state, social entrepreneurs have to constantly care about the quality of their services and about the search for funding sources.

An important aspect of successful social entrepreneurship in St. Petersburg is the availability of the necessary education for employees; people who have received education in various fields are engaged in social entrepreneurship. However, the most successful in this activity are those who have specialized education or completed professional retraining courses.

The information society becomes an important factor in the development of social entrepreneurship interaction. The digital environment allows social entrepreneurs to exchange experiences and does not open up opportunities for social entrepreneurship using digital technologies.

Employees of social-oriented not-for-profit organizations are well aware of the principles of social entrepreneurship; they have the study of the peculiarities of social entrepreneurship at the regional level is an urgent topic for future research. A very promising topic for the theory and practice of social entrepreneurship can be comparative studies of the practice of social entrepreneurship in different regions using a similar methodology positive attitude towards it and consider education an important factor in success in this matter.

We understand the limitations of the current research. We limited the analysis of not-forprofit organization activities within one city (Saint Petersburg, Russia). It is obvious that the sphere of social entrepreneurship has just begun to develop in Russia, and it covers not more than $4 \%$ total commercial activity of other enterprises. It is difficult to find financial resources for this type of activity in Russia. Not-for-profit organizations experience severe competition for state grants.

We believe that it is necessary to study the experience of other Russian cities in this sphere to extract and assess best practices in social entrepreneurship. Future research should cover overseas practices as well. Combining internal and external experience, we can create the complete notion of social entrepreneurship and make it compatible and socially useful activity.

\section{References}

1. N. Almazova, D. Bylieva, V. Lobatyuk, A. Rubtsova, SPBPU IDE'19: Proceedings of Peter the Great St. Petersburg Polytechnic University International Scientific Conference on Innovations in Digital Economy (ACM Press, 2019) https://doi.org/10.1145/3372177.3373340 
2. D. Bylieva, N. Almazova, V. Lobatyuk, A. Rubtsova, Advances in Intelligent Systems and Computing Cham, Springer 1114 AISC, 545-554 (2019) https://doi.org/10.1007/978-3-030-37737-3_47

3. D. Block de, H. Peter, Feindt, E. Van Slobbe, Ecology and Society 24(1), 1-10 (2019) https://doi.org/10.5751/ES-10310-240119

4. E.G. Pozdeeva, O.D. Shipunova, L.I. Evseeva, IOP Conference Series: Earth and Environmental Science 337, 012049 (2019) https://doi.org/10.1088/17551315/337/1/012049

5. O. Shipunova, L. Evseeva, E. Pozdeeva, V.V. Evseev, I. Zhabenko, E3S Web of Conferences 110, 02011 (2019) https://doi.org/10.1051/e3sconf/201911002011

6. F. Lyon, H. Fernandez, Soc. Enterprise J. 8(1), 63-77 (2012) https://doi.org/10.1108/17508611211226593

7. E.G. Popkova, B.S. Sergi, J. of Intellect. Capital 21(4), 565-581 (2020) https://doi.org/10.1108/JIC-09-2019-0224

8. A. García-González, M.S. Ramírez-Montoya, Proceedings of the Seventh International Conference on Technological Ecosystems for Enhancing Multiculturality 19, 925-929 (2019) https://doi.org/10.1145/3362789.3362794

9. T. Ramus, A. Vaccaro, J. of Business Ethics 143(2), 307-22 (2017) https://doi.org/10.1007/s10551-014-2353-y

10. K. Andre, A. Pache, J. of Business Ethics 133(4), 659-75 (2016) https://doi.org/10.1007/s10551-014-2445-8

11. M. Jilinskaya-Pandey, J. Wade, J. of Social Entrepreneurship 10(3), 265-287 (2019) https://doi.org/10.1080/19420676.2018.1541013

12. J. Thompson, G. Alvy, A. Less, 38(5), 328-338 (2000) https://doi.org/10.1108/00251740010340517

13. J.G. Dees, J. Elias, Ethics Quarterly 8(1), 165-178 https://doi.org/10.2307/3857527

14. E. Muralidharan, S. Pathak, Sustainability 11(4), 1-19 (2019) https://doi.org/10.3390/su1 1040965

15. S.A. Zahra, E. Gedajlovic, D.O. Neubaum, J.M. Shulman, J. of Business Venturing 24(5), 519-532 (2009) https://doi.org/10.1016/j.jbusvent.2008.04.007

16. E. Sahan, J. of Fair Trade 1(2), 14-23 (2019) DOI:10.13169/jfairtrade.1.2.0014

17. R. Harding, Business Strategy Review 15(4), 39-43 (2004) https://doi.org/10.1111/j.0955-6419.2004.00338.x

18. B. Doherty, H. Haugh, F. Lyon, Intern. J. of Management Reviews 16(4), 417-436 (2014) https://doi.org/10.1111/ijmr.12028

19. M.T. Dacin, P.A. Dacin, P. Tracey, Organiz. Sci. 22(5), 1203-1213 (2011) https://doi.org/10.1287/orsc.1100.0620

20. P.N. Bloom, A.K. Chatterji, California Management Rev. 51(3), 114-133 (2009) https://doi.org/10.2307/41166496

21. E. Shaw, S. Carter, J. of Small Business and Enterprise Development 14(3), 418-434 (2007) https://doi.org/10.1108/14626000710773529

22. M. Powell, A. Gillett, B. Doherty, Public Management Rev. 21(2), 159-186 (2019) https://doi.org/10.1080/14719037.2018.1438504

23. R. Ridley-Duff, Intern. J. of Entrepreneurial Behaviour \& Research 4(5), 291-312 (2008) https://doi.org/10.1108/13552550810897669 
24. I. Bozhikin, J. Macke, L. Folchinida, J. of Cleaner Production 226, 730-747 (2019) https://doi.org/10.1016/j.jclepro.2019.04.076

25. A.W. Montgomery, P.A. Dacin, M.T. Dacin, J. of Business Ethics 111(3), 375-388 (2012) https://doi.org/10.1007/s10551-012-1501-5

26. P. Gupta, S. Chauhanb, J. Paulc, M. Jaiswald, J. of Business Research 113, 209-229 (2020) https://doi.org/10.1016/j.jbusres.2020.03.032

27. L. Farinha, J.R. Sebastião, C. Sampaio, et al., Intern. Rev. on Public and Nonprofit Market 17, 77-96 (2020) https://doi.org/10.1007/s12208-020-00243-6

28. I. Arribas, Management Decision 50(10), 1739-1757 (2012) https://doi.org/10.1108/00251741211279576

29. P. Bonin-Rodriguez, N. Vakharia, Artivate 9(1), 3-7 (2020) https://doi.org/10.34053/artivate.9.1.122

30. H. Rawhouser, M. Cummings, S.L. Newbert, Entrepreneurship Theory and Practice 43(1), 82-115 (2017) https://doi.org/10.1177/1042258717727718

31. J. Austin, H. Stevenson, J. Wei-Skillern, Entrepreneurship Theory and Practice 30(1), 1-22 (2006) https://doi.org/10.1111/j.1540-6520.2006.00107.x

32. J. Thompson, Internat. J. of Public Sector Management 15(5), 412-431 (2002) https://doi.org/10.1108/09513550210435746

33. T. Saebi, N.J. Foss, S. Linder, J. of Management 45(1), 70-95 (2018) https://doi.org/10.1177/0149206318793196

34. C. Seelos, J. Mair, Business Horizons 48(3), 241-246 (2005) https://doi.org/10.1016/j.bushor.2004.11.006

35. P.A. Dacin, M.T. Dacin, M. Matear, Academy of Management Perspectives 24(3), 3757 (2010) https://doi.org/10.5465/amp.24.3.37

36. I. Lee, J. Soc. Entrepreneurship and Innovation 3(4), 269-300 (2015) https://doi.org/10.1504/IJSEI.2015.069351

37. M. Aydogmus, Studies in High. Edu. 44(2), 1-15 (2009) https://doi.org/10.1016/j.jbusres.2019.02.031

38. J. Weerawardena, G.S. Mort, J. of World Business 41(1), 21-35 (2006) https://doi.org/10.1016/j.jwb.2005.09.001

39. O. Lehner, E. Grabmann, C. Ennsgraber, Venture Capital: An Intern. J. of $\begin{array}{llll}\text { Entrepreneurial } & \text { Finance } & \mathbf{1 7}(\mathbf{1 - 2}), & 171-189\end{array}$ DOI:10.1080/13691066.2015.1037132

40. G. Alarifi, P. Robson, E. Kromidha, J. of Soc. Entrepreneurship 10(3), 1-21 (2019) https://doi.org/10.1080/19420676.2018.1541015

41. S. Bansal, I. Garg, G. Sharma, Sustainability 11(4), 1-28 (2019) https://doi.org/10.3390/su11041091

42. J. Lecy, H. Schmitz, H. Swedlund, Intern. Soc. for Third-Sector Research 3, 434-457 (2012) https://doi.org/10.1007/s11266-011-9204-6

43. S. Van Puyveld, R. Caers, C. Du Bois, M. Jegers, Public Management Review 18(2), 1-17 (2014) https://doi.org/10.1080/14719037.2014.969760

44. B. Din, A. Anuar, M. Usman, 6th International Research Symposium in Service Management, IRSSM-6 2015. Procedia - Social and Behavioral Sciences 224, 117-123 (2015) https://doi.org/10.1016/j.sbspro.2016.05.413

45. D. Smeets, J. of Soc. Entrepreneurship 8(1), 67-87 (2017) https://doi.org/10.1080/19420676.2017.1299034 
46. S. Verbruggen, J. Christiaens, Canadian J. of Administrative Sci. 29(3), 205-217 (2012) https://doi.org/10.1002/cjas.1219

47. S.G. Mort, J. Weerawardena, K. Carnegie, Intern. J. of Nonprofit and Voluntary Sector Marketing 8(1), 76-88 (2003) https://doi.org/10.1002/nvsm.202

48. J.C. Short, T.W. Moss, G.T. Lumpkin, Strateg. Entrepreneurship J. 3(2), 161-194 (2009) https://doi.org/10.1002/sej.69

49. E. Douglas, C. Prentice, J. of Business Research 99, 69-79 (2019) https://doi.org/10.1016/j.jbusres.2019.02.031

50. D. Bylieva, N. Almazova, V. Lobatyuk, A. Rubtsova, Advances in Intelligent Systems and Computing Cham, Springer 1114 AISC, 545-554 (2019) https://doi.org/10.1007/978-3-030-37737-3_47 